\title{
THE EFFECT OF SOCIAL MEDIA TO THE BRAND AWARENESS OF A PRODUCT OF A COMPANY
}

\author{
Hansel Bagus Tritama ${ }^{1}$ and Riswan Efendi Tarigan ${ }^{2}$ \\ Program of Information System, Faculty of Computer Science \\ University of Pelita Harapan, Jakarta 15811, Indonesia \\ Email: ${ }^{1}$ hanselgunawan94@gmail.com, ${ }^{2}$ re.tarigan@gmail.com
}

\begin{abstract}
Social media is an online media, where the users can easily participate, share, and create any content such as banner, posters, videos and advertisement. Many companies use these social media as a tool to promote their products and make customers aware with their brand. On the other hand, not all companies succeed to market their products and make their products are at their customers' awareness. The purpose of this research is to find the correlation between social media communication marketing with companys brand awareness in social media. The research method for this research is quantitative research. This method collects data with explanative research type which explains the relationship between two variables. The result of this research is to show that marketing communication in a company has an impact to company's brand awareness. In addition, this research wants to show that marketing via social media can give impact to company's revenue. The summary of this research is to get significant information about the effect of social media toward companys brand awareness through quantitative and explanative research method due to the rising of social media.

Keywords: Social Media; Marketing Communication; Online Marketing; Brand Awareness.
\end{abstract}

\section{INTRODUCTION}

Business competition through social media is getting tougher. It can be seen from the rising number of social media user. This development can be seen from the rise of social media user in a relatively short period of time. In 2002, the first social media named Friendster was created by British programmer named Jonathan Abrams. He managed to popularize this social media to Asia. But unfortunately, Friendster could not last long. In 2004, a social media named Facebook was created by Mark Zuckerberg and he managed to influence the world with an effect called The Facebook Effect [1], which has succeeded to make Friendster abandoned.

Received: Nov. 16, 2015; received in revised form: Jan. 19, 2016; accepted: March 1, 2016; available online: May 12, 2016.
After that, two years later, a new social media came up with the name of Twitter. Twitter was created by Jack Dorsey, a programmer from the United States.

Twitter even rose up and replaced Facebook as the highest levels of the company's revenue in 2008 [2]. Not long after, in 2010, a social media emerged and became popular in 2013, it is Instagram that was created by Kevin Systrom, a programmer from Massachusetts. Instagram attracts the attention of many people including business people, even top artists such as Justin Bieber and Katy Perry's use Instagram to promote their new song [3].

Then, a new social media Path recently emerged in 2011, which its shares are owned by Bakrie. Path is a new social media that was created by Dave Morin a programmer from San Francisco. Now Path is still in developmental stages. With the rapid development of social media, many companies see this as their chance to show their products to the public. So the company should have a superior marketing strategy to attract the attention of social media users, especially for corporate marketing communication division.

The result of previous research shows that the role of marketing communications of a company in social media affects the awareness of social media users on a brand of a company. The result of previous research presented by Ref. [4] shows the adoption of an integrated marketing communications can build a corporate brand in the minds of consumers or customers. The process begins to build awareness of the company's products to customers and then it will give impact to customers' satisfaction and establish customers' loyalty to the company.

Although social media has been widely used by many companies as a facility to show their products to the users of social media, there are still many companies that do not succeed in marketing their prod- 
Cite this article as: H B Tritama and R E Tarigan, "The Effect of Social Media to the Brand Awareness of a Product of a Company", CommIT Journal, vol. 10, no. 1, pp. 9-14, 2016.

ucts in social media. The result of previous research, conducted by Ref. [5] shows that it is due to the information that is managed by companies is less attractive so that people do not respond. In this study, the role of social media as a new trend in marketing will be explored more deeply to raise customer awareness of a brand of a company. This research is expected to produce a maximum contribution, assuming the time of the income generated by the impact of social media on the brand awareness of the company's products is two months, from the date of May 27, 2014 until July 31, 2014.

Based on the above background, the problem is then formulated to provide guidance and direction of this research. Do social media give a significant impact on the communitys brand awareness of companys products? Is there any significant relationship between social media marketing communication of a company with brand awareness of a product in the community? The purpose of this study is to determine the effect of social media on the brand awareness of the company's products. Results of this study will provide recommendations for the management of the company or organization to increase its marketing strategy, especially on social media.

\section{SUPPORTING THEORIES}

\section{A. Social Media}

Social media is a collection of applications based on the basis of web 2.0 and it allows the user to fill its content. Social media will stop if there is not any user filling content. The characteristic of social media is the message that is conveyed not only for one person but also for many people. The message tends to be faster than the other media since the interaction with many users makes this media lively. Social media can be in the form of forums, microblogging, social networking, social bookmarking, and wiki [6].

\section{B. Marketing Communications}

Marketing communications is a means for a company to inform, persuade and remind consumers directly or indirectly about their products and brands. Marketing communications presents a "voice" of a company and its brand and a means of a company to create a dialogue and build relationships with consumers.

Marketing communications is able to describe the manufacturer of the product and what the objectives of a company and a brand. Marketing communications enables a company to connect a brand with people, places, experiences, feelings, and other things. They contribute to the brand awareness of company's products by placing the brand in people's memories. They create a brand image as well as encourage the sale and even affect shareholder value [7].

\section{Advertising}

Advertising are all paid form of nonpersonal presentation and promotion of ideas, goods, or services through a clear sponsorship [8].

\section{Brand Awareness}

Brand awareness is the ability of a potential buyer to recognize and recall a brand as part of a particular product category. Brand awareness requires continum ranging from feeling of uncertainty that a particular brand has been known before, so the consumer believes that the product is the only brand in a particular group. Brand awareness is divided into four stages, namely brand unaware, brand recognition, brand recall and top of mind. The lowest level of brand awareness is the brand recognition or it is also called as levels of aided recall. The next level is brand recall or unaided brand recall since the consumers do not need to be helped to remember the brand. The measurement of unaided brand recognition is more difficult than aided brand recognition. The aid in aided brand recognition can be a poster, video, advertisements, banners, or social media. The next level is a brand that is introduced for the first time in unaided brand recognition and it is called top of mind (conscious top of mind). Top of mind is the highest brand awareness that is on the top of other different brands that exist in the minds of consumers [9].

\section{E. Online Media}

Online media, also called Digital Media, is a media that is presented online on the internet. Online media is divided into two definitions.

Definition of online media in general is any kind or media format that can only be accessed via internet containing text, images, video, and sound. Online media can also be interpreted as a means of online communication. Therefore, e-mail, mailing lists, websites, blogs, whatsapp and social media is in the category of online media. Definition of Online Media in particular is an online media in the context of mass communication. Media short of mass communication media in the scientific field of mass communication have certain characteristics, such as publicity and periodicity. Online media in particular is a medium that presents the work of journalism (news, articles, feature) online [10]. 
Cite this article as: H B Tritama and R E Tarigan, "The Effect of Social Media to the Brand Awareness of a Product of a Company”, CommIT Journal, vol. 10, no. 1, pp. 9-14, 2016.

\section{F. Previous Research}

Research conducted by Ref. [11] supports this research. Their research proves the influence of advertising messages on facebook fanpage, which is a social media, to the awareness of the company's products and buying interest from women. This has implications for the company's marketing communications strategy, especially the promotion through advertising.

Research conducted by Ref. [4] suggests that the Marketing Communications variables influence the Brand Equity Products. This proves that the marketing communications of a company plays an important role in selling the company's products. Research conducted by Ref. [12] suggests that Kaskus online banner and advertisement give a significant influence on improving the image of Kaskus. In addition, the calculation result of correlation indicates that Kaskus banners and advertisement relate strongly to the Kaskus brand image with a value of 0.517 . It has more than 0.500 and this means strong influence. Not only that, this study also shows a strong Guilford correlation between two variables.

Research conducted by Ref. [13] shows the influence of social media on the benefits of a brand called Coffee Toffee. The result shows that there are four variables in social media that can give effect to the users of social media. These variables are social media as a means of communication with the loading factor of 0.98 , as Media Campaign with the loading factor 0.93, as a Means of Research with loading factor 0.91, and as Brand Awareness Enhancing with the loading factor of 0.87. Research conducted by Ref. [14] suggests that advertising on the Internet simultaneously gives significant influence on buying interest of Blackberry. In addition, advertising on social media also gives influence the public perception of a product. This proves that advertising through social media can give effect to the brand awareness of the company's products.

These previous researches indirectly support this research on the question of whether there is a significant influence of social media on a company's brand awareness.

\section{RESEARCH METHODS}

\section{A. Types of Research}

Explanatory research aims to test a theory or hypothesis to strengthen or even reject the theory or hypothesis of the research that already exists. Exploratory research has a fundamental nature and it aims to obtain explation, information and data about things that are not yet known. Because it has a fundamental nature, this study is called exploration. Some questions are prepared as a guide to obtain primary data in the form of explanation and information, as preliminary data required. Explanatory research goal is to test a study with a view to justify or strengthen and determine the nature of the relationship between one or more symptoms or dependent variables by one or more independent variables

This type of research is based on the basic question of "why". Through this explanatory research, it can be seen how the correlation between two or more variables in pattern, direction, nature, form, and strength of the relationship. This correlational study was started with implicit or explicit question: "Is there a relationship between $X$ and $Y$ ?", where $X$ is the independent variable and $Y$ is the dependent variable. In addition, this type of research is also relatively good for beginners who are just doing research [15].

\section{B. Research Model}

The research model is shown in Fig. 1. Independent variables in the research model above are adopted from previous research but it has carried out modification and addition of new variables in order to contribute to existing research.

Research conducted by Ref. [11] uses two independent variables. They are Advertisement Message Attaction $\left(X_{1}\right)$ which has a coefficient of Cronbach's for 0.948 and Buying Interest on Women $\left(X_{2}\right)$ with a coefficient of Cronbach's for 0.962. Five independent variables are used in the research conducted by Ref. [4] but the content of these variables are different. The variables are Sales Promotion $\left(X_{1}\right)$, Public Relations $\left(X_{2}\right)$, Direct Marketing $\left(X_{3}\right)$, Interactive Marketing $\left(X_{4}\right)$ and Corporate Design $\left(X_{5}\right)$, all of these variables influence the Brand Equity.

In the research conducted by Ref. [12], three independent variables are used. They are the Strength of Brand Association $\left(X_{1}\right)$, Favorability of Brand Association $\left(X_{2}\right)$ and Uniqueness of Brand Association $\left(Y_{3}\right)$.

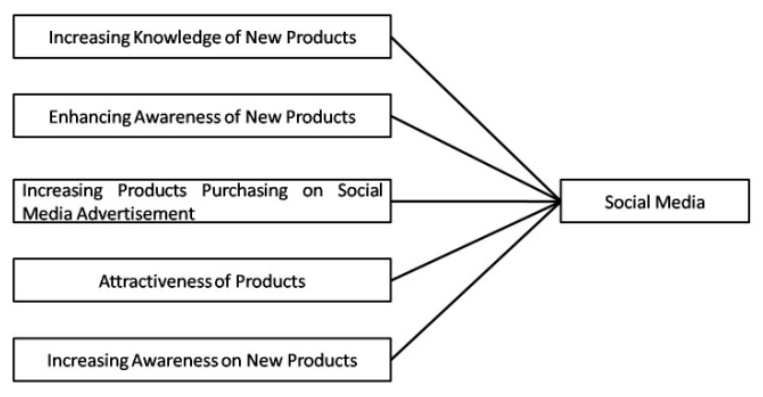

Fig. 1. Research Model. 
Cite this article as: H B Tritama and R E Tarigan, "The Effect of Social Media to the Brand Awareness of a Product of a Company", CommIT Journal, vol. 10, no. 1, pp. 9-14, 2016.

Research conducted by Ref. [13] uses four independent variables. They are Means of Communication $\left(X_{1}\right)$, Media Campaign $\left(X_{2}\right)$, Research Medium $\left(Y_{3}\right)$ and More Popular Brand $\left(X_{4}\right)$. Four independent variables are used in a research conducted by Ref. [14]. They are Effectiveness of Advertising $\left(X_{1}\right)$, Reference $\left(X_{2}\right)$, Perceived Quality $\left(X_{3}\right)$ and Buying Intention $\left(X_{4}\right)$.

Based on the explanation above, it shows that several variables used were adopted from previous studies but there are also variables that are modified to be able to contribute to existing or future research. Thus, this research may proceed to a deeper research.

\section{Hypotheses}

The hypothesis is a proportion, condition or principles that are temporarily considered to be true and perhaps without an assurance for logical consequence to be drawn and then the results of the conducted research is examined. The current hypotheses are:

$\mathrm{H}_{0}$ : Social media is considered to have a very significant influence on factors such as enhancement of new products awareness, new product intense recall, products buying interest, product attraction and swiftness of new product awareness.

$\mathrm{H}_{1}$ : Factors that are considered most affected dominantly is product attraction.

\section{Population dan Sample}

Population of this research is 50 students from Faculty of Computer Science and Information Systems Study Program of Pelita Harapan University, class of 2011-2012 who use social media. Sampling (a tool that represents the population) is taken by using Simple Random Sampling (SRS). This technique takes a random sample of population members and assumes all of the students of social media users are homogeneous or they have the same opportunity to become members of the sample [16]. Sample that is going to be examined is set by using the Slovin formula:

$$
n=\frac{N}{1+N e^{2}}
$$

where $n$ is sample number, $N$ is population number, $e$ is error tolerance, as if $2 \%, 5 \%$, or $10 \%$.

Total population in this research has been determined as many as 50 people. Error tolerance limits is assumed at 5\%, so it has a 95\% accuracy rate. By using this Slovin formula, the number of samples studied can be determined, where the process of calculation is $n \approx 43$.

\section{RESULTS AND DISCUSSIONS}

\section{A. Respondent Profile}

The current empirical data were collected from 50 respondents, $70 \%$ male and $30 \%$ female. They were 19 to 21 years old, $30 \%$ were 19 year old, $45 \%$ were 20 year old, and $25 \%$ were 21 year old. All were users of social media and had highschool level of education. The data were collected on June 2014.

\section{B. Validity and Reliability}

To meet the criteria of a research which is considered as scientific research, measurement accuracy is indispensable [17]. There are two main requirements that must be met by the measuring instrument to obtain an accurate measurement, the validity and reliability. Validity means measuring instruments used to measure what is to be measured [17].

Validity test is intended to test the accuracy of the items in the questionnaire, whether the items are able to describe and explain the variables studied. So validity is the extent to which the tool can measure a matter or subject to be measured. Validity is done with a logical mind, by asking the opinion of experts, using recognized groups and independent criteria [18]. Items used in this study were then tested for its reliability.

Reliability means having trustworthiness. When the measuring instrument is used many times, it still provides the same results [18]. So reliability is how consistent the measuring devices provide the same results in measuring the same matters and subjects.

\section{Validity Test}

Validity test that is used to measure whether the questionnaire is valid or invalid in this study is correlation validity test of product moment Pearson. This test is done by calculating the correlation between the values obtained from each question to the overall value or the total value derived from questionnaire data [19] by using SPSS 16.0 for Windows. The validity of the data can be seen from the value of $r$ (correlation coefficient) with testing significance level of 0.05 . If $r$-count is larger than $r$-table then the questionnaire as measuring instrument is valid. However, if the $r$ count is smaller than $r$-table then the questionnaire as a measuring instrument is invalid. The value of $r$-table can be obtained via the official website of SPSS Indonesia. Large or small of the value of $r$ table depends on the number of questions written in the questionnaire $(N)$.

Total population studied is as many as 50. Then the distribution of the value of $\mathrm{r}$ table with the $5 \%$ significance is equal to 0.279 . Questionnaire is made 
Cite this article as: H B Tritama and R E Tarigan, "The Effect of Social Media to the Brand Awareness of a Product of a Company”, CommIT Journal, vol. 10, no. 1, pp. 9-14, 2016.

TABLE I

QUESTIONNAIRE OF SOCIAL MEDIA INFLUENCE ON BRAND AWARENESS OF PRODUCT COMPANY 2014.

1 Social media is good to be used as a marketing tool of company products.

2 Any trade or service company should have social media as marketing tools.

3 Advertising through social media is more quickly recognized by the community rather than advertising through other media (such as newspapers, TV, and radio).

4 Social media can attract more customers to the company products.

5 Ads that draw attention to social media determines the selling of company products.

6 I know a lot of new products from social media.

7 Social media helps me to remember new products.

8 I like to buy a product from the ads on social media

in accordance with the theory of Likert, where every statement is divided into five points, namely Strongly Agree (SA), Agree (A), Doubtful (D), Disagree (Da) and Strongly Disagree (SDa).

The contents of the questionnaire is divided into two, where the numbers 1-5 are questionnaires about the influence of social media $(X)$, where the data will be examined as the dependent variables. While the numbers $6-10$ is a questionnaire about the brand awareness of the company's products in the community $(Y)$, where the data will be examined as independent variables. The questionnaire is shown in Table I.

\section{CONCLUSIONS}

Social media gives a significant influence on a company's product brand awareness in the community. It is based on the results of the analysis using corellation bivariate where social media significantly affect any independent variables (Brand awareness of the products of a company in the public) with values Significance 2-tailed at each independent variables less than or equal to 0.05 which which means to have a significant influence.

Social media gives a significant influence on the enhancement of the product attraction to the product marketing that circulates on social media. This can be seen in the results of analysis using Corellation Bivariate where relationships dependent variables (Social Media) and independent variables (Product Attraction) have a value of Pearson Corellation of 0.861 and it means that it has a very strong correlation. It also has a number Significance 2-tailed smaller or equal to 0.05 and it means that it also has a significant relationship. Results of this research at the same time validates the hypothesis (H1) where it says that the most dominant factor affecting the products on Social Media is the attraction of the products in the public. So the statement $\mathrm{H} 1$ is no longer a hypothesis but it has been proven correct.

This research obtains significant results and has a strong correlation suggesting that social media can attract more customers since social media users are interested in the advertisement displayed. The results can be seen in Coefficients table (Table 23) that is generated through the analysis of Linear Regression. It shows that there is a strong correlation relationship between the dependent variables of Social Media Attracts More Customers of Company Products $\left(X_{4}\right)$ and the independent variables of Marketing through Social Media interests Users of Social Media $\left(Y_{4}\right)$ with a correlation figure of 0.893 and it means that it has a very strong correlation.

The influence of social media on the independent variables $5\left(Y_{5}\right)$, Enhancement of New Products Awareness, has the lowest correlation number among the four other independent variables. This can be seen in the results of Correlation Bivariate analysis of the number 5 where Social Media only affects variables of Enhancement of New Products Awareness for 0.675 (numbers in Pearson Corellation) and it means the relationship between the two variables is moderate. However, since the value of Significance 2-tailed is still below 0.05 then the relationship between the two variables can still be said to be significant.

For companies that want to release a new product, they should market their products through social media, because it gives a significant influence on the public awareness of a product. It is already proven that each independent variable formed refers to the dependent variable, and that is social media. All of these variables have Significance 2-tailed numbers smaller or equal to 0.05 and it means it has a significant relationship between social media and brand awareness of a companys product Future studies could consider other variables associated with brand awareness of a product on social media, such as Increasing Company Product in Capital Markets or Increasing Corporate Weekly Sales. Addition or alteration of these other variables is to convince companies about the significant role of social media to their products. 
Cite this article as: H B Tritama and R E Tarigan, "The Effect of Social Media to the Brand Awareness of a Product of a Company”, CommIT Journal, vol. 10, no. 1, pp. 9-14, 2016.

\section{REFERENCES}

[1] D. Kirkpatrick, The Facebook Effect. Simon \& Schuster Paperbacks, 2010.

[2] J. Comm, Twitter Power 2.0: How to Dominate Your Market One Tweet at a Time. Wiley, 2010.

[3] J. Miles, Instagram Power: Build Your Brand and Reach More Customers with the Power of Pictures. McGraw-Hill Education, 2014.

[4] N. P. Kartikasari, "Pengaruh komunikasi pe- masaran terpadu terhadap ekuitas merek," INTERAKSI: Jurnal Ilmu Komunikasi, vol. 3, no. 2, pp. 162-167, 2014.

[5] R. Syaukat and E. Imanjaya, "Film sebagai media social marketing: Berjualan ide multikulturalisme," Humaniora, vol. 2, no. 1, pp. 634-642, 2011. [Online]. Available: http: //kineforum.org/web/wp-content/uploads/2012/10/ Film-sebagai-Media-Social-Marketing.pdf 